\title{
IS HEIGHT/AGE A RELIABLE INDEX OF SITE?
}

\author{
BY A. B. VINCENT ${ }^{1}$
}

Born in 1921, Mr. A. B. Vincent served in the Canadian Army from 1940 to 1945 . He received a B.Sc.F. degree from U.N.B. in 1949 and an M.Sc.F. degree from U.N.B. in 1954. From 1949 to 1955 he was employed by the Forestry Branch on the Green River Project in New Brunswick and from 1956 to 1960 was Executive Officer at the Petawawa Forest Experiment Station, Chalk River, Ontario. At present he is working as a member of the Department of Forestry on problems in black spruce in Ontario.

\section{ABSTRACT}

Uses of the total-height/total-age relationship and the growth-intercept method in defining site quality are discussed briefly. Factors affecting height growth of the trees such as animal, insect, and frost damage, along with stand density and initial suppression, are discussed. Attention is drawn to their influences on the height-age relationship. It is suggested that the growthintercept method of obtaining site quality may be useful in some circumstances.

\section{INTRODUCTION}

The use of total height over age as an index of site quality is not as simple as some textbooks on forest mensuration might lead one to believe. A review of literature indicates that many foresters have used the totalheight/total-age ratio as a site index for one purpose or another, often in preparing yield tables, but few appear to have looked at it critically or noticed any particular problems connected with obtaining reliable height indices.

The purpose of this article is to point out that the concept of site index must be used with caution, and to indicate some of the limitations imposed by nature.

\section{Generai}

Frothingham (1918) believed that he and Russel Watson were the first in North America to use the height/age relationship as an index of site quality. He discussed its utility and pointed out advantages and disadvantages. He listed eight features of using height growth as a guide to site, three of which are: (1) it is simple, natural, easily understood, and easily applied in the field; (2) it is independent of the determination of physical sites producing definite permanent forms of forest; and (3) the sites determined by height growth are species sites, not permanent type sites, hence they are useful with reference to short-lived intolerant and to long-lived tolerant species growing in the same stand.

Frothingham listed as disadvantages the following: (1) height growth is too sensitive to incidents in the history of the life of the stand, such as origin (i.e. sprout or seed), changes in density, and interferences in the normal growth of the stand, such as cutting, fire, grazing, etc.; (2) the mere determination of site on the basis of height growth tells nothing about the factors

\footnotetext{
'Research Officer, Forest Research Branch, Department of Forestry, Octawa.
} 
which produce it, nor what the same site would produce if other species were grown, nor whether even the same species would grow equally in height on the same site a second time under the same or a different kind of treatment; and (3) a given species may exhibit the same height growth on widely different sites, as in swamps and on dry uplands. That this last is strictly a disadvantage may be open to argument.

Roth (1916), Watson (1917), and others writing on the subject during the same period discussed critically the idea of using tree height to evaluate site. Following this there appears to have been extensive use of the method with little critical examination of possible problems involved, until the past decade. Spurr (1952) was somewhat more critical than Meyer (1953) when discussing the subject, but concluded that height growth is perhaps the best single measure of site although it is not a perfect one.

Others have discussed the pros and cons of using heights of dominant trees only or dominant and co-dominant trees combined. Some appear to have used both while referring to them as dominants. Ker (1952) concluded that the use of heights of dominant trees only is satisfactory in immature Douglas fir.

Also during the past decade a considerable interest has arisen in the use of only a part of the height growth of the tree as a site index. The paper by Wakeley and Marrero (1958) was an illustration of the interest in this index. Various workers have used somewhat different methods, but the basic idea is to measure the height growth which takes place during a freegrowing period of the tree. Growth near breast height over a period of five years appears to be favoured. Wakeley and Marrero called this the fiveyear intercept method, and show it to be a useful method of expressing site index in pine plantations in the southern United States.

\section{Factors Afpecting Height/Age Relationship}

Many things may happen to a tree which can alter the height-age relationship so as to obscure any differences ascribed to site. With the passage of time, the evidence of these happenings becomes obscure and can be detected only by stem analysis. Although such things are natural in the forest, the investigator must strive to avoid their influence if he is to obtain reliable site indices. He may do this by learning to recognize the occurrence of these factors and rejecting trees so affected, or he may assess their effects in his area and make allowances for them in calculating site index.

A number of factors, other than direct site influences, which may affect the rate of height growth are discussed below.

\section{Mammal Damage}

Several writers have reported on squirrel damage to trees. Balch (1942) reported that red squirrels nip off shoots of balsam fir very commonly, particularly on trees just approaching maturity. Hosley (1928) found 93 per cent of Scots pine and 68 per cent of Norway spruce in plantations damaged by squirrels. Red spruce, red pine, and white spruce were ignored. This damage appeared to coincide with periods of heavy snowfall. Rowe (1952) in Manitoba found squirrels had caused extensive damage to white 
spruce by clipping leaders about one inch below the terminal buds. The damage affected trees from saplings to veterans, and coincided with a cone crop failure. Stiell (1960), working in white spruce plantations at Petawawa Forest Experiment Station, found evidence of squirrels clipping leaders in current and past years. Leaders sometimes were killed back two years, and estimates of height growth were made rather uncertain.

In a study of height-age-site relationships in New Brunswick, the author (Vincent 1954a) found squirrel and other damage to leaders so prevalent that unaffected trees for stem analysis were almost impossible to find. In another but previously unreported study in 35-40 year old spruce-fir stands which had developed since the 1913-19 spruce budworm outbreak, the author found 77 per cent of fir and 85 per cent of white spruce had suffered squirrel damage to leaders. The leaders of affected trees were clipped an average of three times and a maximum of ten. A concurrent examination of stems in mature stands showed that the leaders of 91 per cent of the mature fir had been clipped, some as many as 15 times. External evidence of this was usually slight, showing mainly as a slightly depressed seam around the stem and completely undetectable from the ground. The total effect of this damage on the height growth rate is unknown, but it must be considerable since the lateral branch which takes over is normally shorter than the leader it replaces.

Most foresters are familiar with the damage to small trees caused by browsing of moose, deer, and rabbits. Many trees which have been browsed for several years survive and reach maturity, at which time all external evidence of browsing has completely disappeared. Damage of this kind can cause a considerable change in the total-height/total-age relationship.

Porcupines often completely girdle the upper part of the stem, but most trees which survive this show unmistakable evidence of the damage and are unlikely to be selected for site index measurements.

\section{Insect Damage}

Damage by insects to the upper parts of trees may reduce height growth and later become undetectable from the ground. Brown (1959) discussed weevil damage to eastern white pine and mentioned its effect on height growth. Ostrander (1952) studied the effects of weevil damage on height growth of white pine. He found that individual trees were attacked up to 11 times each. For every four external indications of weevil attack, there were five found when the trees were cut up. Brown ${ }^{2}$ reported that, on the Spanish River watershed in Ontario, dominant height of jack pine at 50 years varies from 50 to 75 feet on the same soil and same topographic position within a distance of 100 feet. The low heights are due to damage to the growing tips by Petrova albicapitana Busck.

In analyzing the height growth of spruce and fir, the author (1954a) found that most of the trees had been affected by the spruce budworm outbreak of 1913-19. Very few trees had escaped completely, and most had about five years height growth killed back. This was sometimes evident from

\footnotetext{
${ }^{2}$ Brown, W. G. E. Paper on site presented to 1952 meeting of District Forest Officers of the Forest Research Division.
} 
the ground from a crook in the stem or the dead stub protuding. More often there was no external evidence of damage which could be detected, even with binoculars, until the tree was felled. On these trees the dead stub apparently had broken off quickly and the wound was quickly grown over. In a distance of two inches along the stem at this point, there was a difference of five years in the ring count.

\section{Stand Density}

Many writers have discussed the effects of stand density on height growth. The prevailing opinion appears to be that the effect is important only at the extremes and is not normally a factor to be considered in assessing height growth. Lorenz and Spaeth (1947) found that density had little effect on height growth in plantations of white and Scots pine, European larch, and Norway spruce. Mann and Whitaker (1952) found that plantation densities ranging from 250 to 2,500 trees per acre in slash pine had no influence on height growth of dominants. However, stands are so variable and so many investigators have had difficulty because of the influence of density that it must be considered. Gaiser and Merz (1951) found that stand density influences site index in white oak, and conclude that variations of height growth with density could cause differences of 10 to 20 per cent in yield. Meyer (1928) found site index in immature Douglas fir to be influenced by density, as did Parker (1942) in lodgepole pine. Parker cited two stands separated only by a freguard: one was 43 years old with a dominant height about 10 feet greater than the other which was more dense and was 73 years old. Smithers (1956) also found dominant heights of lodgepole pine affected by density sufficiently to hide any possible differences which might have been caused by variations in physiographic site. The author (Vincent, 1954b) found that stand density in a 35-40 year old spruce and fir stand strongly influenced height growth in all crown classes. Dominant tree height at 1,000 trees per acre was 43 feet, while at 5,300 trees per acre it was only 32 feet.

\section{Growth Rate Variation}

There is also an indication that site index at certain ages is not a true index for certain combinations of species and site. Heiberg and White (1954) pointed out that some trees on poorer sites grow faster at middle age than on the best site at the same age. Lorenz and Spaeth (1947) found that plantations on prairie soils grew very rapidly for the first 25 to 30 years but site index appeared to change with age when compared with standard site index curves. Rowe (1953a), working with white spruce in Manitoba, found that a single tree may during its lifetime successively be classed as "good", "fair", or "poor" when judged by conventional site index curves. He stated that dominant trees from the same tenth-acre plot often have different patterns of growth. He ascribed this to variations in genetic background, history, and micro-environment which apparently cause considerable differences even between neighbouring trees.

\section{Frost Damage}

Cayford et al (1959) found that winter drying and late spring frosts materially reduced terminal and lateral growth. They found that up to 65 
per cent of the buds of white spruce and balsam fir were killed. Ontkean and Smithers (1959) in Alberta found 42 per cent of 656 white spruce examined had height growth affected by animals, insects, and frost damage to terminal buds. Trees involved were up to 70 years old.

Although frost damage may not be an important factor in many areas and probably need not be considered unless it is epidemic or subject to control, there are localities where it may upset normal height/age relationships.

\section{Suppression}

Suppression of tolerant species in youth is often found. Morris (1948) studied balsam fir in New Brunswick and found initial suppression up to 30 years common, and some trees had been suppressed up to 100 years. On being released these trees had the same growth rate and reached sexual maturity at the same time as unsuppressed trees which were the same size when the suppressed trees were released. Mount and Gove (1952) found that 92 per cent of red spruce examined had initial suppression lasting beyond 1 inch d.b.h., and it lasted beyond 2 inches for 77 per cent. Also in red spruce, McLintock and Bickford (1957) found that only three of 54 trees, which were selected as being apparently unsuppressed from seedling age, did not show one or more well-defined suppression periods lasting 17 to 69 years. They concluded that unsuppressed red spruce are too rare to be relied on for site index determination where age is used as a variable. Rowe (1953b) mentioned that white spruce seedlings started on rotten wood require 20 to 30 or more years to reach breast height, while seedlings on a clean burnpresumably mineral soil-reach breast height in 10 to 15 years. To this might be added the differences in growth rate between layers and seedlings of black spruce.

Most foresters are familiar with the problems involved in accurate age determination. Much attention has been given to this in Europe and North America without any easily used field method having been developed.

\section{FaCtors AfFecting the GROWTH-INTERCEPT METHOD}

While the growth-intercept method of calculating site index is undoubtedly useful in certain circumstances, it too has limitations. Two are obvious. The first is that the early height growth of a tree is not always indicative of the height it will attain at maturity. For example, variability in soil horizons may result in the tree growing rapidly in youth but slowing well before maturity. Conversely, it may grow slowly when young but much more rapidly in later years, i.e., growth might be slow on a coarse, dry soil, but increase rapidly if roots reach a richer, moister soil layer at depth.

The second obvious limitation is that growth curves for some species, obtained from the section in the vicinity of breast height, will not show clearly the difference between sites. That is, the curve for one site will parallel that of a better or poorer site when drawn using growth data from the part of the stem immediately above breast height.

The method does, however, have the advantage that such factors as mammal and insect damage, initial suppression, and stand density are operative 
over a shorter period, thus tending to have a lesser cumulative effect on the height/age relationship than is found in the total-height/total-age relationship.

\section{Conclusions}

The height/age relationship as an index of site has been in use in North America since about 1917. Some foresters have used it while realizing that it has inherent limitations for which allowance must be made. Others have apparently ignored these limitations when using it. The factors discussed emphasize these limitations. However, used with regard for the draw-backs imposed by nature, it is still probably the best single indicator of site quality.

The growth-intercept method of obtaining a site index is subject in lesser degree to the factors which influence the total-height/total-age relationship. Its main value would appear to be in immature natural stands or plantations where mature trees are not available for site index measurements.

Each forester using the height/age relationship as a site index should be aware of the factors discussed in this article. Their influence may be little or great in his area, but he cannot afford to ignore them completely if his indices are to be reliable. How he can take their effects into account is a problem for which there is no clear solution with the present state of knowledge. Identifying and avoiding trees which have had interrupted height growth is one possibility but, as suggested previously, this is often difficult without expensive stem analyses. It could also lead to a biased sample. Another possibility is to assess the effects of the various factors and make allowances when calculating and using site index curves. This also would require expensive investigations, but once done might permit more reliable indices to be obtained.

Finally, in addition to the foregoing factors affecting site indices, there are other problems worthy of the attention of competent mensurationists. Some of these were discussed by Ker and Smith (1957) and include (1) refinement of presently available means of assessing site index, (2) the true forms of height/age curves for each species and each site index, (3) explicit definitions of the number, class, and age of trees required for a fair assessment of site index, (4) the relationship, in young stands, between current and apparent site index, and (5) the influence of stocking on height growth.

\section{REFERENCES}

BALCH, R, E. 1942. A note on squirrel damage to conifers. For. Chron. $18(1): 42$. BROWN, RAYMOND C. 1959. Insect damage and control. In What's known about managing eastern white pine. U.S.D.A. Northeast. F.E.S., Station Paper No. 121.

CAYFORD, J. H., HILDAHL, V., NAIRN, L. D. and M. P. H. WHEATON. 1959. Injury to trees from winter drying and frost in Manitoba and Saskatchewan. For. Chron. $35(4): 282-290$.

FROTHINGHAM, E. H. 1918. Height growth as a key to site. Jour. For. 16:754-760.

GAISER, R. N., and R. W. MERZ. 1951. Stand density as a factor in estimating white oak site index. Jour. For. 49:572-574.

HEIBERG, SVEND. O., and DONALD P. WHITE. 1954. A site evaluation concept. Paper presented before winter meeting, New England Section, Society of American Foresters, Boston.

HOSLEY, N. W. 1928. Red squirrel damage to coniferous plantations and its relation to changing food habits. Ecology 9:43-48. 
KER, J. W. 1952. An evaluation of several methods of estimating site index of immature stands. For. Chron. $28(3): 63-74$.

KER, J. W. and J. H. G. SMITH. 1957. How much and how fast-Forest measurements today, Parts $I$ and II. B.C. Lumberman 41:30-4, 94-102, February and March.

LORENZ, R. W., and J. NELSON SPAETH. 1947. The growth of conifers on prairie soil. Jour. For. 45:253-256.

MANN, W. F. JR., and L. B. WHITAKER. 1952. Stand density and pine height growth. U.S.D.A., Southern Exp. Sta., Southern Forestry Note No. 81.

McLINTOCK, T. F., and C. A. BICKFORD. 1957. Site index for red spruce. U.S.D.A., Northeastern F.E.S., Station Paper No. 93.

MEYER, H. A. 1953. Forest mensuration. vïi + 357. Penns. Valley Publishers Inc., State College, Penn.

MEYER, W. H. 1928. Rates of growth of immature Douglas fir as shown by periodic remeasurements on permanent sample plots. Jour. Agric. Res. 36(3):193-215.

MORRIS, R. F. 1948. How old is a balsam tree? For. Chron. 24(2):106-110.

MOUNT, PETER, and WILLIAM GOVE. 1952. Site index for spruce-fir stands based on age at breast height and total height. University of Maine, For. Dept. Tech. Note No. 13.

ONTKEAN, G., and L. A. SMITHERS. 1959. Growth of Alberta white spruce after release from aspen competition. Can. Dept. of North. Aff. and Nat. Res., For. Br., For. Res. Div., Mimeo 59-1.

OSTRANDER, M. D. 1957. Weevil attacks apparently unrelated to height of eastern white pine. U.S.D.A., Northeast. F.E.S. For. Res. Note No. 67.

PARKER, H. A. 1942. Dominant height and average diameter as a measure of site in untreated even-aged lodgepole pine stands. Can. Dept. Mines and Resources, Dom. For. Serv., Silv. Res. Note No. 72.

ROTH, F. 1916. Concerning site. For. Quart. 14-3-12.

ROWE, J. S. 1952. Squirrel damage to white spruce. Can. Dept. Res. and Dev, For. Br. Silv. Leaflet No. 61.

ROWE, J. S. 1953 a. Forest sites, Riding Mountain Experimental Area. Can. Dept. North. Aff. and Nat. Res., For. Res. Div., Unpub. MS.

ROWE, J. S. 1953b. Forest sites. For. Chron. 29(3):278-289.

SMITHERS, L. A. 1956. Assessment of site productivity in dense lodgepole pine stands. Can. Dept. North. Aff. and Nat. Res., For. Res. Div., Tech. Note No. 30.

SPURR, S. H. 1952. Forest inventory. xii +476 . The Ronald Press Co., N.Y.

STIELL, W. M. 1960. Thinning white spruce plantations at Petawawa to fixed basal areas. Can. Dept. North. Aff. and Nat. Res., For. Res. Div., Unpub. MS.

VINCENT, A. B. 1954a. A preliminary study of the correlation of the height/age relationship of spruce and fir, and site. Can. Dept. North. Aff. and Nat. Res. Div., Unpub. MS.

VINCENT, A. B. 1954b. The development of balsam fir thickets in the Green River watershed following the spruce budworm outbreak of 1913-1919. Master's Thesis. University of New Brunswick.

WAKELEY, P. C., and J. MARRERO. 1958. Five-year intercept as site index in southern pine plantations. Jour. For. 56:332-336.

WATSON, R. 1917. Site determination, classification and application. Jour. For. 15:552-563. 